\title{
TRADISI DALAM MODERNISASI PENDIDIKAN ISLAM DI INDONESIA
}

\author{
Muhammad Riduan Harahap \\ Fakultas Agama Islam Universitas Al Washliyah (UNIVA) Medan \\ Jl. Sisingamangaraja KM. 5,5 No. 10 Medan
}

\begin{abstract}
Abstrak: Pembahasan dalam tulisan ini menunjukkan bahwa pendidikan Islam dalam menghadapi arus modernisasi masih tetap berupaya mempertahankan berbagai tradisi-tradisi tertentu yang sebagiannya berimplikasi positif, meskipun sebagian lagi berimplikasi negatif bagi upaya memajukan pendidikan Islam di era modern.Tradisi-tradisi yang dipertahankan itu berkaitan dengan kurikulum, metode pembelajaran, budaya akademik dan lainnya.Pada unsur kurikulum, tradisi klasik itu misalnya terlihat dalam bentuk masih adanya upaya pelestarian turats (kitab-kitab kuning). Pada sisi lain, di pesantren-pesantren modern juga masih dihidupkan tradisi belajar dengan mendayagunakan masjid sebagai sarana yang merupakan salah satu tradisi klasik yang hidup di pesantren tradisional. Tradisi lain yang masih tetap dipertahankan di dunia pesantren modern adalah berkaitan dengan pola hubungan kiai dan santri yang tetap terjaga dan bahkan menjadi kata kunci kekhasan pesantren, begitu juga dengan tradisi-tradisi klasik lainnya.
\end{abstract}

Kata Kunci :Tradisi,Modernisasi, Pendidikan Islam, Indonesia

\section{Pendahuluan}

Tulisan ini kurang lebih merupakan upaya untuk memberikan jawaban atas pertanyaan berikut: "apakah modernisasi masih menyisakan tradisi, atau bagaimanakah nasib tradisi-tradisi yang dimiliki pendidikan Islam Indonesia dalam menghadapi arus modernisasi itu'?.Memberikan penjelasan mengenai pertanyaan ini menurut pemakalah sangat penting setidaknya mengingat beberapa hal ini.

Pertama, Pada kenyataannya bahwa dalam menghadapi perubahan dan tantangan yang dibawa oleh modernisasi itu, lembaga pendidikan Islam cenderung bersikap sangat hati-hati.Hal ini sebagaimana misalnya analisis Nor Huda bahwa pesantren tidak begitu saja dan cepat-cepat mentransformasikan kelembagaan pesantren menjadi lembaga pendidikan modern Islam sepenuhnya.Mereka menerima pembaruan atau modernisasi pendidikan Islam hanya dalam skala yang sangat terbatas, yaitu sebatas mampu menjamin pesantren untuk tetap survie. Semua proses penyesuaian dengan modernisasi itu dilakukan oleh pesantren tanpa 
mau mengorbankan esensi dan hal-hal dasariyah dari eksistensi pesantren itu sendiri. ${ }^{1}$

Kedua, bahwa modernisasi itu mengandung semangat atau ambisi yang kuat untuk "menghabisi" tradisi-tradisi tertentu yang dimiliki pesantren selama ini-sebagaimana kesan seperti itu misalnya dapat ditemukan di pesantren Darul Mursyid Simanosor Kabupaten Tapanuli Selatan.Ketiga, di sisi lain, bahwa lembaga-lembaga pendidikan Islam di era modern, disadari atau tidak masih tetap terpenjara oleh tradisi-tradisi tertentu yang kurang mendukung bagi kemajuan.

Karenanya, tulisan ini akan menjelaskan bagaimana lembaga-lembaga pendidikan Islam secara sadar mempertahankan tradisi-tradisi tertentu yang dimilikinya dalam berhadapan dengan modernisasi baik itu tradisi-tradisi yang berimplikasi positif maupun negatif, atau di sisi lain akan menjelaskan bagaimana tradisi-tradisi klasik tertentu yang dipandang kurang atau tidak relevan masih menjangkiti pendidikan Islam di era modern.

\section{Tradisi dan Modernisasi}

Pembahasan tentang modernisasi tentu tidak bisa melepaskan diri dari pembahasan tentang tradisi, sebab salah satu yang bersentuhan langsung dengan gerakan modernisasi itu adalah tradisi.Di Negara-negara muslim yang mengalami atau menjalankan modernisasi banyak muncul upaya atau gerakan untuk mempertahankan tradisi yang dimiliki, yang kemudian digolongkan sebagai kaum tradisional.

Kaum tradisional dalam Islam terkadang disebutjuga sebagai kaum fundamentalis yang ciri fundamentalnya adalah menerima Alquran secara literal.Salah satu paham umum kaum tradisional Islam adalah pandangannya tentang dunia yang statis.Bagi tradisionalis ini, ketidakberubahan (unchangingnes) merupakan suatu hal yang ideal bagi individu dan masyarakat.Ketidakberubahan ini merupakan asumsi berpengaruh luas yang mewarnai hampir seluruh aspek paham tradisional.Bahkan ulama tradisional ini biasanya tidak mengakui adanya

${ }^{1}$ Nor Huda, Sejarah Sosial Intelektual Islam di Indonesia (Jakarta: RajaGrafindo Persada, 2015), h. 314-315 
pengembangan, dan mengklaim bahwa semua doktrin yang benar sudah ada sejak zaman Muhammad Saw. ${ }^{2}$

William Montogomery dalam kajiannya mengemukakan bahwa diterimanya doktrin ketidakberubahan ini baik sebagai fakta maupun cita-cita diduga kuat bermula dari pengalaman kehidupan Nomadik bangsa Arab, yang mengakibatkan timbulnya paham bahwa keselamatan terletak pada upaya mengikuti sunnah para leluhur. Menurutnya, bangsa Arab Nomad tentu saja menyadari perubahan, di mana suku-suku berhasil dan berkembang semakin meningkat, lalu mengalami nasib pahit, mundur dan terkadang lenyapsekaligus. Namun demikian, perubahan seperti itu bagi mereka tidak berarti bahwa pada dasarnya kehidupan itu mengalami perubahan, sehingga bagi mereka lebih baik melakukan apa-apa yang telah dilakukan "nenek moyang” sebab dalam banyak hal cara itu justru membuahkan hasil memuaskan. Di samping itu, iklim Arabia itu tidak menentu dan tidak teratur, sehingga orang Nomad seringkali tidak dapat menghindari bencana dengan membuat rencana-rencana cermat, sehingga terpaksa membiasakan diri untuk menerima apa saja yang terjadi pada dirinya. Corak pemikiran yang seperti ini menurutnya yang mengakibatkan doktrin mengikuti “jejak leluhur" merupakan opini paling kuat, dan segala yang baru, biasanya pasti akan dicurigai. ${ }^{3}$

Berkaitan dengan itu, Fazlur Rahman menegaskan bahwa gagasan yang menyatakan bahwa teknologi modern yang bermanfaat dapat diperkenalkan dalam suatu masyarakat dengan tetap bisa memelihara integritas tradisi masyarakat tersebut tentu saja merupakan gagasan yang naï.Namun mereka yang berpandangan sebaliknya, di mana modernisasi teknologi dengan sendirinya melibatkan westernisasi besar-besaran juga adalah merupakan gagasan yang tidak kurang naifnya. ${ }^{4}$

Paham tradisional ini memang berkaitan dan berhadapandengan peradaban modern Barat.Dalam konteks ini, tradisi dalam Islam itu dipahami sebagai produk pemikiran serta nilai-nilai yang mencakup agama, etika, estetika, dan spritualisme

\footnotetext{
${ }^{2}$ William Montogomery Watt, Islamic Fundamentalism and Modernity, Terjemahan Kurnia Sastrapraja dan Badri Khaeruman (Bandung: Pustaka Setia, 2003), h. 11-12

${ }^{3}$ Ibid, h. 14-15

${ }^{4}$ Fazlur Rahman, Islam dan Modernitas: Tentang Transformasi Intelektual (Bandung: Pustaka, 1985), h. 57
} 
yang berada di wilayah sana-artinya berada di luar lingkungan peradaban modern Barat.Muhammad Abed Al Jabiri menegaskan bahwa umat Islam saat ini merasakan sendiri hidup di tengah-tengah rimba peradaban modern Barat.Saat mereka berinteraksi dengannya atau malah mencangkoknya dan mengimpikan untuk terlibat secara sadar di dalamnya, maka umat Islam justru merasakan adanya kesenjangan yang begitu lebar antara peradaban modern Barat tersebut dengan warisan tradisi yang dimilikinya. ${ }^{5}$

Menurutnya, jurang pemisah antara "yang ada di sana (tradisi masa lalu umat Islam) dan yang ada di sini (peradaban modern Barat saat ini) semakinbertambah lebar dan tambah curam. Perasaan dan kesadaran semacam ini lah yang kemudian memperkuat adanya rasa rindu dan romantisme di kalangan umat Islam terhadap tradisinya, meskipun pada sebagian yang lain tertanam harapan untuk melepaskan diri dan putus hubungan dengan tradisi itu. ${ }^{6}$

Fazlur Rahman meposisikan kaum fandamentalis dengan gerakan revivalisnya sebagai pihak yang berupaya untuk tetap mempertahankan tradisi di tengah upaya pembaharuan.Mereka inilah yang kemudian disebut kaum tradisionalis.Menurutnya, gerakan modernis awal telah memunculkan dua kecenderungan yang terpecah yaitu antara westernisme belaka dan yang mengarah pada fundamentalisme atau yang disebut dengan revivalisme. ${ }^{7}$

Kaum konservatif-fundamentalis yang kemudian disebut tradisionalis meyakini bahwa kaum modernis sebenarnya diilhami oleh liberalisme Barat, yang diambil isinya untuk kemudian diusahakan mencari penopangnya dari Alquran. Ini kemudian menjurus pada keucurigaan mereka yang lebih mendalam bahwa kaum modernis rela 'menjual' nilai tradisional muslim apa pun, bahkan termasuk prinsip-prinsip dasar, demi komoditas budaya Barat. Menurut Rahman,keadaan ini dipandang sebagai bentuk kegagalan modernisme Muslim yang membiarkan modernisme itu langsung disamakan dengan westernisme. Padahal sebenarnya tidak ada yang aneh dalam upaya kaum modernis dalam meminjam pola dan ragam budaya Barat, karena inilah memang yang dilakukan setiap perdaban yang

${ }^{5}$ Muhammad Abed Al Jabiri, Post Tradisionalisme Islam, Terjemahan (Yogyakarta: LKiS, 2000), h. 17-18

${ }^{6}$ Ibid, h. 18

${ }^{7}$ Fazlur Rahman, Islam: Sejarah Pemikiran dan Peradaban (Bandung: Mizan, 2017), h. 
sedang tumbuh, dan hal ini jugalah yang telah dilakukan oleh Islam di zaman dulu.Akan tetapi bedanya menurutnya adalah bahwa Islam di zaman dulu tidak bisa dikatakan semata-mata meminjam, tetapi juga mengislamkan dan mengintegrasikannya ke dalam kerangka nilai-nilai Islam yang kemudian diperluas jika dirasa kurang memadai. ${ }^{8}$

Kaum tradisionalis yang terkadang disebut fundamentalis dan konservatif ini juga senantiasa dipertentangkan dengan kaum liberal yang berpandangan bahwa paham tradisional harus dikoreksi dalam beberapa hal dan perlunya dilakukan pembaruan.Ulama yang merupakan pencetus dan penyebar utama paham tradisional ini kebanyakan bersikap reaksioner, dalam arti cenderung menentang pembaruan.Namun meski demikian, di kalangan orang-orang yang disebut konservatif atau tradisional ini terdapat pula berbagai unsur reformis, dan terkadang mereka sangat kritis terhadap ulama dan melakukan pembaruan. Pembaruan-pembaruan yang ingin dilakukan kaum reformis hampir semuanya menyangkut bidang sosial dan politik, dan pada saat yang sama mereka membiarkan paham umum tradisional tidak berubah. ${ }^{9}$ Sementara kaum liberal bukan hanya ingin mengubah paham tradisional tersebut, bahkan ingin melakukan pembaruan-pembaruan lainnya.

Pada sisi lain, Seyyed Hussein Nasr mengemukakan bahwa tradisional Islam itu merupakan suatu gerakan yang berupaya membangkitkan tradisi Islam sebagai suatu realitas spiritual di tengah modernism. Penekanan gerakan tradisional Islam ini menurutnya adalah pada perubahan batin masyarakat Islam secara keseluruhan. ${ }^{10}$ Bagi Nasr, tradisonal Islam melindungi syari'ah seutuhnya sebagai hukum Tuhan dan menempatkan sufisme sebagai dimensi terdalam dari titik kebangkitan Islam era modern. ${ }^{11}$

${ }^{8}$ Ibid, h. 349

${ }^{9}$ Watt, Islamic Fundamentalism, h. 11. Model kaum tradisonal seperti ini bisa dibandingkan dengan pemikir-pemikir reformis NU yang meski di satu sisi mereka dikelompokkan sebagai kaum tradisionalis, namun mereka tetap terbuka dengan modernitas bahkan menggagas pemikiran-pemikiran yang dinamis di Indonesia. Lihat Martin Van Bruinessen, Traditionalist Muslims in A Modernizing World: The Nahdlatul Ulama and Indonesia's New Order Politics, Factional Conflict, and The Search for A New Discourse, Diterjemahkan Farid Wajidi, (Yogyakarta: LKiS Yogyakarta, 1999), h. 13

${ }^{10}$ Seyyed Hossein Nasr, Islam Tradisi di Tengah Kancah Dunia Modern (Bandung: Penerbit Pustaka, 1994), h.91

${ }^{11} \mathrm{Ibid}$, h. 92 
Dalam konteks masyarakat muslim Indonesia juga telah terjadi pemilahan antara Islam tradisionalis yang berupaya menjaga tradisi Islam dan Islam modernis yang menggerakka pembaruan-pembaruan. Di sini, Islam modernis diwakili oleh Muhammadiyah, Persis, dan lain-lain; dengan Islam tradisionalis diwakili oleh NU dan sebagainya.Itu pula lah sebabnya pembentukan NU pada tahun 1926 itu seringkali dijelaskan sebagai bentuk reaksi defensif terhadap berbagai aktifitas kelompok reformis Muhammadiyah-yang gencar mendirikan sekolah-sekolah bergaya Eropa, dan juga terhadap kelompok modernis-moderat yaitu Sarekat Islam (SI). ${ }^{12}$

Meskipun sebenarnya-sebagaimana dikemukakan Azra bahwa pengelompokan tipologi modernis yang diwakili Muhammadiyah dan tradisionalis yang diwakili NU ini sudah menjadi tidak relevan lagi.Sebab, pada faktanya kesan yang tampak justru NU sering menampilkan sikap yang modernis dan sebaliknya Muhammadiyah terlihat tradisionalis. Menurut Azra sebenarnya pengelompokan itu merupakan bias intelektual di mana orang yang paling bertanggung jawab terhadap penyebaran distingsi yang bias itu adalah Deliar Noer. Karena itulah maka Azra merumuskan tipologi gerakan Islam yang dipandangnya lebih objektif pada tiga kelompok yaitu subtansialisme, legalisme/formalisme, dan spritualisme. $^{13}$

Pengelompokan tipologi seperti itu memang wajar dipandang tidak relevan sebab pada kenyataannya meskipun NU digolongkan sebagai kaum tradisionalis di Indonesia, namun tidak bisa ditutupi mereka bukanlah sama sekali anti modernisasi. Martin menegaskan bahwa NU sebagai muslim tradisional Indonesia bahkan memiliki sejumlah pemikir yang meskipun berlatar belakang pendidikan tradisional di pesantren seperti Abdurrahman Wahid, Musthofa Bisri dan lainnya, namun mereka juga adalah ulama yang memiliki pengetahuan tentang modernitas, sehingga tidak terjadi penentangan yang begitu berarti terhadap arus modernisasi. Antara tradisi dan transformasi yang dibawa modernisasi itu bagi pemikir-pemikir NU bukanlah hal-hal yang sepenuhnya berbeda dan saling bertentangan.Tradisi dan modernitas bagi mereka merupakan sebuah pasangan yang menyatu dan

\footnotetext{
${ }^{12}$ Ibid, h.3-17

${ }^{13}$ Azyumardi Azra, Islam Reformis, Dinamika Intelektual dan Gerakan (Jakarta: Raja Grafindo Persada, 1999),h. 60-61
} 
saling membutuhkan.Bahkan, gagasan-gagasan kaum tradisionalis muslimNU ini lah justru yang telah menyumbangkan lahirnya wacana Islam yang lebih dinamis, lebih menarik dan merangsang di Indonesia dibandingkan sumbangan muslim fundamentalis. ${ }^{14}$

Tampaknya, kenyataan ini jugalah yang mendorong Mark R.Woodward pada kesimpulan bahwa di Indonesia, seseorang bisa saja menjadi pribadi yang sangat modern, dan pada saat bersamaan juga tampil sebagai pribadi yang sangat Muslim sekaligus. ${ }^{15}$

Namun demikian, pada faktnya tetap saja terdapat tradisi-tradisi tertentu yang menjadi faktor pemicu terjadinya pertentangan antara kaum tradisionalis NU dengan kaum pembaharu di Indonesia.Sebagai misal adalah kritik paling keras yang ditujukan terhadap amalan kaum tradisionalis berkaitan dengan hubungan antara orang yang masih hidup dengan orang yang sudah meninggal dunia. Kaum pembaharu menyatakan bahwa kematian berarti berakhirnya komunikasi antar manusia dan upaya-upaya untuk berhubungan dengan arwah orang yang sudah meninggal dunia, dengan tujuan apa pun merupakan penyimpangan dari ajaran tauhid. Mereka dengan tegas menolak kepercayaan kepada pertolongan arwah dan bentuk-bentuk kontak spiritual lainnya; pemujaan wali dikutuk sebagai amalan yang bertentangan dengan ajaran Islam.Tahlilan, slametan, dan ziarah yang bagi kalangan tradisionalis merupakan amalan keagamaan yang sangat penting, sangat dibenci oleh kaum pembaharu, sebab menurut mereka, satu-satunya amalan yang sah yang dapat dilakukan untuk kerabat yang sudah meninggal adalah berdoa secara langsung kepada Allah dan memohon ampun atas dosa-dosanya. ${ }^{16}$

Antara Tarikan Modernisasi dan Upaya Mempertahankan Tradisi di Lembaga Pendidikan Islam Indonesia.

Dalam konteks pendidikan Islam di Indonesia, tarik menarik antara upaya mempertahankan tradisi dengan modernisasi itu sangat jelas terjadi sebagaimana

\footnotetext{
${ }^{14}$ Bruinessen, Traditionalist, h. 13

${ }^{15}$ Mark R.Woodward, Modernity And The Disenchantment Of Life: A Muslim-Christian ContrastDalam Johan Meuleman (Ed.), Muslim Attitudes Towards Modernity and Identity (New York: RoutledgeCurzon, 2002), h. 81

${ }^{16}$ Bruinessen, Traditionalist, h. 24-25
} 
misalnya di pesantren.Sehubungan dengan ini, menurut Qodri Azizy-tak pelak lagi pesantren harus menyeimbangkan antara warisan tradisi dengan modernisasi. Pesantren ke depan harus memadukan warisan tradisi dan modernisasi. Keseimbangan ini akan membawa pesantren ke arah kemajuan. Pondok pesantren ke depan harus memadukan warisan tradisi dan modernisasi. Keseimbangan ini akan membawa pesantren ke arah kemajuan. Menurutnya, beragam tradisi yang dimiliki pesantren seperti kemandirian, independensi, dan keunggulan pemikiran keagamaan adalah modal berharga untuk melangkah ke depan. Sementara kemajuan modernisasi tidak boleh dihindari karena memang tidak terelakkan. Artinya, untuk tetap survive dan mengembangkan diri ke depan, satu-satunya pilihan adalah memadukan tradisi yang dimilikinya dengan kemajuan zaman di luar pesantren. ${ }^{17}$

Di kalangan cendekiawan muslim telah terjadi pro kontra tentang keharusan mempertahankan pesantren dengan berbagai tradisi yang dimilikinya. Dr.Sutomo merupakan orang yang termasuk pro untuk tetap mempertahankan pesantren dalam pengertian tradisional tanpa adanya pembaharuan.Ia melihat bahwa pesantren merupakan lembaga pendidikan sebagai wadah integrasi kultural, tidak saja dalam arti integrasi nilai di antara para santri dan berbagai latar belakangnya, tetapi juga integrasi antara santri dan masyarakat sekitar. Sementara Sutan Takdir Ali Syahbana-cendikiawan berpendidikan Barat bersikap kontra dan mendorong dilakukannya modernisasi terhadap pesantren.Ia mengemukakan bahwa yang terpenting baginya adalah tersebarnya ilmu pengetahuan modern sampai ke desa-desa dan itu akan berarti robohnya tradisi lama, terpecahnya persatuan yang statis dan pasif dan lenyapnya konservatisme. ${ }^{18}$

Respon pendidikan Islam tradisional terhadap arus modernisasi itu pun sangat hati-hati. Karel Steenbrink menyatakan bahwa pendidikan Islam tradisional dalam konteks surau tradisional di Minangkabau menunjukkan sikap "menolak dan mencontoh" terhadap modernitas, sementara dalam konteks pesantren bersikap “menolak sambil mengikuti”. Berdasarkan itu juga, steenbrink menolak

17 Thonthowi, "Pendidikan dan Tradisi: Menakar Tradisi Pendidikan Pesantren" dalam Tadris: Jurnal Pendidikan Islam Fak. Tarbiyah STAIN Pamekasan (Vol. 3 No. 2. 2008), h. 163

18 Haidar Putra Daulay, Pendidikan Islam dalam Sistem Pendidikan Nasional di Indonesia (Jakarta: Prenada Media Group, 2012), h. 34 
beberapa pandangan dunia kaum reformis, bahwa kaum tradisi di Minangkabau memandang ekspansi sistem dan kelembagaan pendidikan modern Islam sebagai ancaman langsung terhadap eksistensi dan kelangsungan surau.Karenanya, mereka memandang bahwa surau yang mereka miliki bahkan harus mengadopsi meskipun hanya beberapa unsur dari pendidikan modern yang telah diterapkan kaum reformis-khususnya sistem klasikal dan penjenjangan. ${ }^{19}$

Sikap enggan menerima modernisasi itu terlihat jelas misalnya dalam rapat antara ulama tradisional yang tergabung dalam Persatuan Tarbiyah Islamiyah (PERTI) di rumah dan atas bimbingan Sulaiman Ar-Rasuli-seorang pemilik surau di Candung (sekitar 9 KM dari Bukit Tinggi).Dalam rapat ini diundang beberapa ulama yang dalam beberapa hal tidak setuju dengan aliran pendidikan Madrasah Diniyah (modern) yaitu Sumatera Thawalib dan PGAI atau kelompok kaum muda.Dalam rapat inilah mereka menyadari dan menunjukkan keterkejutan terhadap kenyataan bahwa surau yang mereka miliki itu tidak begitu laku lagi, bahkan mulai kosong karena banyak siswanya yang pindah ke Madrasah Diniyah Sumatera Thawalib yang sudah modern untuk ukuran saat itu.Karenanya, pada pertemuan tersebut para ulama tradisional-secara mau tidak mau memutuskan untuk mengambil meskipun hanya beberapa unsur pendidikan modern seperti sistem kalsikal, sebagaimana misalnya yang dilakukan Syaikh Abbas dari Ladang Lawas dengan mendirikan Arabiyah School pada tahun 1918 dan mendirikan sekolah kedua di Bukit Tinggi dengan sistem klasikal. ${ }^{20}$

Berdasarkan itu, dapat dipahami bahwa di kalangan pendidikan Islam telah muncul sikap enggan antara mengikuti tarikan modernisasi atau tetap mempertahankan tradisi yang sudah mengakar selama ini. Meskipun surau dan pesantren tidak menolak modernisasi, namun pada awalnya mereka hanya berkenan mengadopsi sebagian saja dari aspek-aspek modern itu-yang dalam bahasa Azra hanya sekedar untuk memastikan pesantren bisa survive.

\section{Tradisi Klasik dalam Pendidikan Islam Modern}

1. Tradisi-tradisi Pesantren Tradisional

\footnotetext{
${ }^{19}$ Karel A. Steenbrink, Pesantren, Madrasah, Sekolah: Pendidikan Islam dalam Kurun Modern (Jakarta: LP3ES, 1991), h. 62-72

${ }^{20}$ Steenbrink, Pesantren, h. 63-64
} 
Untuk lebih mempertajam pembahasan ini, ada baiknya diawali dengan penjelasan secara ringkas tentang maksud tradisi klasik itu sendiri.Tradisi klasik yang dimaksud dalam pembahasan ini adalah kebiasaan-kebiasaan yang hidup dan berlaku di lingkungan pesantren tradisional-sebagai lembaga pendidikan Islam indigenous, khususnya yang berkaitan dengan kurikulum, metode pembelajaran, maupun pola hubungan antar santri dengan guru/kiai.Sehubungan dengan itu, Van Bruinessen mencatat bahwa identitas tradisi intelektual pesantren itu pada awal berdirinya ditentukan oleh tiga serangkai mata pelajaran, yang terdiri dari fiqih menurut mazhab Syafi'i, akidah menurut mazhab Asy'ari dan amalan-amalan Sufi dari karya-karya Imam Al-Ghazali. ${ }^{21}$

Tradisi pesantren itu berbentuk kebiasaan-kebiasaan yang hidup dan berkaitan dengan berbagai elemen pembentuk pesantren itu sendiri. Sebuah pesantren biasanya terdiri dari lima elemen dasar yang terdiri dari: pondok, masjid, santri, pengajaran kitab-kitab Islam klasik dan kiai. ${ }^{22}$

Pertama, Pondok. Istilah pondok berasal dari pengertian asrama-asrama para santri (pondok) atau tempat tinggal yang dibuat dari bambu, atau barangkali berasal dari kata Arab funduq, yang berarti hotel atau asrama. ${ }^{23}$ Keadaan pondok sebagai tradisi khas pesantren pada masa kolonial digambarkan Hurgronje sebagaimana dikutip Arifin pondok terdiri dari dari sebuah gedung berbentuk persegi, biasanya dibangun dari bambu, tetapi di desa-desa yang agak makmur tiang-tiangnya terdiri dari kayu dan batangnya juga terbuat dari kayu. Tangga pondok dihubungkan ke sumur oleh sederet batu-batu titian, sehingga santri yang kebanyakan tidak bersepatu itu dapat mencuci kakinya sebelum naik ke pondoknya. Pondok yang sederhana hanya terdiri dari ruangan besar yang didiami bersama oleh santri. ${ }^{24}$

Kedua, Masjid. Masjid merupakan elemen yang tidak dapat dipisahkan dengan pesantren dan dianggap sebagai tempat yang paling tepat untuk mendidik para santri, terutama dalam praktek sembahyang lima waktu, khutbah dan

\footnotetext{
${ }^{21}$ Bruinessen, Traditionalis, h. 21

${ }^{22}$ Zamakhsyari Dhofier, Tradisi Pesantren Studi tentang Pandangan Hidup Kiai (Jakarta: LP3ES, 1982), h. 44.

${ }^{23}$ Ibid., h. 18 .

${ }^{24}$ Imron Arifin, Kepemimpinan Kiai, Kasus: Pondok Pesantren Tebuireng (Malang: Kalimasahada Press, 1993), h. 6.
} 
sembahyang Jum'ah, dan pengajaran kitab-kitab Islam klasik. ${ }^{25}$ Kedudukan $^{2}$ masjid sebagai pusat pendidikan dalam pondok pesantren merupakan manifestasi universalisme dari sistem pendidikan Islam tradisional, sebab sejak zaman lahirnya Islam (Nabi Muhammad), masjid telah menjadi pusat pendidikan Islam. Para kiai selalu mengajar murid-muridnya (santri) di masjid dan menganggap masjid sebagai tempat yang paling tepat untuk menanamkan disiplin kepada santri dalam mengerjakan sholat lima waktu, memperoleh pengetahuan agama dan kewajiban agama yang lain. Oleh karena itu, masjid merupakan elemen penting dari sebuah pondok pesantren.

Ketiga, Santri. Santri merupakan peserta didik atau objek pendidikan di pesantren. ${ }^{26}$ Santri merupakan sebutan bagi para siswa yang belajar mendalami agama di pesantren, para santri tinggal dalam pondok yang menyerupai asrama biara, dan disana mereka memasak dan mencuci pakaiannya sendiri, mereka belajar tanpa terikat waktu sebab mereka mengutamakan beribadah, termasuk belajarpun dianggap sebagai ibadah. ${ }^{27}$

Keempat, Pengajaran kitab-kitab Islam klasik.Penyebutan kitab-kitab Islam klasik di dunia pondok pesantren lebih populer dengan sebutan "kitab-kitab kuning", tetapi asal usul istilah ini belum diketahui secara pasti. Menurut Nasuha sebagaimana dikutip oleh Arifin, penyebutan batasan term kitab kuning, mungkin membatasi dengan tahun karangan, ada yang membatasi dengan madzhab teologi, ada yang membatasi dengan istilah mu'tabarah dan sebagainya. Sebagian yang lain beranggapan disebabkan oleh warna kertas dari kitab-kitab tersebut berwarna kuning, tetapi argumen ini kurang tepat sebab pada saat ini kitab-kitab Islam klasik sudah banyak dicetak dengan memakai kertas putih yang umum dipakai di dunia percetakan. ${ }^{28}$

Kitab-kitab kuning yang diajarkan di pondok pesantren dapat digolongkan kedalam 8 kelompok, yaitu: 1. Nahwu dan Saraf; 2. Fiqh; 3. Ushul fiqh; 4. Hadis; 5. Tafsir; 6. Tauhid; 7. Tasawuf dan Etika; 8. cabang-cabang ilmu lain seperti

\footnotetext{
${ }^{25}$ Dhofier, Tradisi Pesantren, h. 49.

${ }^{26}$ Mujamil Qomar, Pesantren Dari Transformasi Metodologi Menuju Demokratisasi Institusi (Jakarta: Erlangga, 2002), h. 20.

${ }^{27}$ Arifin, Kepemimpinan Kiai, h. 11.

${ }^{28}$ Ibid, h. 8-9.
} 
Tarikh dan Balaghah. ${ }^{29}$ Kitab kuning dan pesantren merupakan dua sisi (aspek)yang tidak bisa dipisahkan, dan tidak bisa saling meniadakan. Ibarat mata uang, antar satu sisi dengan sisi lainnya yang saling terkait erat. ${ }^{30}$ Kitab kuning sebagai salah satu unsur mutlak dari pengajaran di pondok pesantren sedemikian penting dalam proses terbentuknya kecerdasan intelektual dan moralitas kesalehan pada diri santri. Oleh karena itu eksistensi kitab kuning dalam sebuah pondok pesantren menempati posisi yang urgen, sehingga dipandang sebagai salah satu unsur yang membentuk wujud pondok pesantren itu sendiri, di samping kiai, santri, masjid dan pondok.

Kelima, Kiai. Di lingkungan pondok pesantren, keberadaan kiai sangat signifikan. Segala bentuk pemikiran, tindak tanduk, dan perilaku kiai dipandang selalu benar serta menjadi figur teladan bagi santri. Kiai kemudian memiliki otoritas dan kharisma yang memuncak, dimana ketaatan santri menjadi sesuatu yang sangat niscaya.Kiai di mata santri lebih dari sekedar guru dalam pengertian modern yang dikenal saat ini. Kiai adalah sosok yang dicontoh segala perilakunya dan digali ilmunya. Bahkan dalam konteks pondok pesantren, kiai berwujud sebagai raja-raja kecil yang memiliki otoritas penuh terhadap pondok pesantren dan santri. Suara kiai adalah titah yang wajib ditaati, karena dalam tradisi pondok pesantren kiai bukan hanya figur spiritual yang memiliki titisan "pewaris para nabi", tetapi juga sebagai simbol penguasa kecil yang sangat otokratif terhadap masyarakat pesantren. Kepatuhan dan ketundukan terhadap kiai dalam segala hal, baik qaulan, fi'lan, dan taqrirannya merupakan fakta ketundukan dalam kehidupan masyarakat pesantren. ${ }^{31}$

Berkaitan dengan metodologi, penyebutan tradisional dalam konteks praktek pengajaran di pesantren itu didasarkan pada sistem pengajaran yang monologis, bukan dialogis-emansipatoris, yaitu sistem doktrinasi kiai kepada

\footnotetext{
${ }^{29}$ Dhofier, Tradisi Pesantren, h. 50

${ }^{30}$ Binti Maunah, Tradisi Intelektual Santri Dalam Tantangan dan Hambatan Pendidikan Pesantren di Masa Depan (Yogyakarta: Teras, 2009), h. 38.

${ }^{31}$ Ibnu Hajar, Kiai Di Tengah Pusaran Politik Antara Petaka dan Kuasa, (Yogyakarta: IRCisoD, 2009), h. 19.
} 
santrinya dan metode pengajaran masih bersifat klasik, seperti sistem bendongan, sorogan, dan sejenisnya. ${ }^{32}$

\section{Tradisi Klasik Dalam Pendidikan Islam Modern}

Tradisi klasik dalam pendidikan Islam modern pada pembahasan ini dimaksudkan masih bertahannya tradisi-tradisi tertentu sebagaimana yang telah dipaparkan sebelumnya, pada lembaga-lembaga pendidikan Islam modern. Haidar Putra Daulay mengemukakan bahwa indikasi atau ciri lembaga pendidikan Islam yang dikategorikan modern itu adalah: Pertama, dimasukkannya mata pelajaran umum ke madrasah. Kedua, penerapan system klasikal dengan segala kaitannya.Ketiga, ditata dan dikelola administrasi sekolah dengan tetap berpegang pada prinsip manajemen pendidikan.Keempat, lahirnya lembaga pendidikan Islam baru yang diberi nama madrasah. Kelima, diterapkannya beberapa mengajar selain metode yang lazim dilakukan di pesantren, seperti sorogan dan wetonan. ${ }^{33}$ Jika kategori ini dijadikan dasar berpikir, maka dapat dipahami bahwa pesantrenpesantren yang ada saat ini hampir semuanya bisa digolongkan sebagai pesantren yang telah modern.Karenanya, lembaga pendidikan Islam modern dalam pembahasan ini bisa saja pesantren yang secara tegas menyebut dirinya sebagai pesantren modern, dan pesantren-pesantren lain yang meskipun masih dipersepsikan sebagai pesantren salafi/tradisional, dan juga di madrasahmadrasah.

Pada kenyataannya, hingga saat ini, tradisi-tradisi klasik tertentu baik yang berkaitan denga kurikulum, metode, bahan ajar, maupun budaya akademik masih tetap dipertahankan di lembaga-lembaga pendidikan Islam tersebut.

Dayah Darul Munawwaroh sebagai salah satu dayah modern di Aceh, hingga hari ini masih tetap mempertahnkan tradisi zaman yang berupa metode halaqah. Dalam praktiknya, di mana seorang teungku duduk di balee dengan

\footnotetext{
${ }^{32}$ Kelompok kelas dalam sistem bendongan ini disebut halaqah yang artinya lingkaran murid, atau sekelompok santri yang belajar di bawah bimbingan seorang guru. Lihat Hasbullah, Sejarah Pendidikan islam di Indonesia(Jakarta: RajaGrafindo Persada, 1995), h. 26

${ }^{33}$ Haidar Putra Daulay, Sejarah Pertumbuhan dan Pembaruan Pendidikan Islam di Indonesia (Jakarta: Prenada Media Group, 2012), h. 60
} 
posisi dikelilingi oleh para santrinya yang diawali dengan membaca matan kitab selanjutnya penjeasan dan terakhir dilakukan tanya jawab. ${ }^{34}$

Penggunaan metode halaqah di Dayah tersebut biasanya dikombinasikan atau dikolaborasikan dengan metode terkini, seperti mengkombinasikannya dengan metode kooperatif (kelompok).Pada pembelajaran dan pembahasan tertentu guru memberikan tugas bagi para santrinya dalam beberapa hari dan setelah waktu yang ditentukan santri diminta untuk menyampaikan tugasnya bersama-sama teungku dan santri lainnya.Sementara metode kooperatif yang dimaksud adalah di mana para santri pada pembahasan tertentu juga diminta membuat kelompok untuk membahas bersama-sama lalu diminta untuk menyampaikan kepada santri-santri lainnya. ${ }^{35}$

Dalam konteks Al Washliyah, upaya mempertahankan tradisi di tengah modernisasi terlihat dalam sistem pendidikan yang diterapkan di Maktab Islamiyah Tapanuli (merupakan cikal bakal organisasi Al Washliyah).Seperti dikemukakan Hasan Asari bahwa kegiatan pendidikan di lembaga ini menggabungkan antara sistem tradisional dan modern.Dari segi isi, materi yang diajarkan di MIT ini tidak jauh berbeda dengan pesantren-pesantren tradisional, meskipun pembelajaran itu telah dilakukan secara klasikal dengan menggunakan media-media modern. Lebih jelas lagi dapat dilihat pada kenyataan bahwa, selain memiliki jenjang persiapan (tahjizi), awal (ibtida'i), dan menengah (tsanawi), lembaga ini juga membuka satu tingkatan lagi di atasnya di mana jenjang ini diberi designasi kelas Azhar di mana diterapkan sistem halaqah dengan duduk di lantai yang menurut Asari terinspirasi dari model Al Azhar Kairo. ${ }^{36}$

Pada unsur kurikulum, tradisi klasik itu juga masih tetap dipertahankan dalam bentuk pelestarian turats (kitab-kitab kuning).Hal ini misalnya dapat dilihat pada Dayah Mudi Mesjid Raya Simalanga Bireuen Aceh.Dalam kurikulum dayah tersebut, khususnya pada jenjang ketiga (Takhassus Ma'had 'Ali) di mana disamping memasukkan pengetahuan umum seperti Bahasa Indonesia, Bahasa Inggris, Matematika, Komputer, Filsafat Umum, Metodologi Penelitian,

\footnotetext{
${ }^{34}$ Zulfikar Ali Buto Siregar, Modernisasi Dayah di Aceh (Disertasi, UIN Sumatera Utara, 2015), h. 189

${ }^{35}$ Buto Siregar, Modernisasi, h. 190

36 Hasan Asari, Modernisasi Islam: Tokoh, Gagasan, dan Gerakan (Bandung: Citapustaka Media, 2002), h. 234
} 
Manajemen Pendidikan, Pengantar Ilmu Hukum, Ilmu Komunikasi, dan Hukum Perdata, juga tetap mempertahankan ilmu-ilmu agama dengan mewajibkan "kitabkitab kuning" sebagai bahan ajarnya. ${ }^{37}$ Ini menunjukkan bahwa di tengah tarikan modernisasi itu muncul upaya lembaga pendidikan Islam untuk mempertahankan tradisi-tradisi yang sudah berakar sebelumnya.

Untuk lebih jelasnya, upaya untuk mempertahankan tradisi khsusnya dalam hal penggunaan kitab kuningdalam kurikulum lembaga pendidikan pasca modernisasi dapat dilihat pada kurikulumDayah Mudi Mesjid Raya Aceh khususnya pada jenjang takhassus ma'had 'aliberikut: ${ }^{38}$

\begin{tabular}{|c|c|c|}
\hline Tingkat/Kelas & Bidang Studi & Nama Kitab Wajib \\
\hline $\begin{array}{l}\text { Takhassus } \\
\text { Ma'had `Ali III }\end{array}$ & $\begin{array}{l}\text { 1. Tauhid } \\
\text { 2. Fiqih } \\
\text { 3. Nahu } \\
\text { 4. Sharaf } \\
\text { 5. Tasawuf } \\
\text { 6. Mantiq } \\
\text { 7. Ushul Fiqih } \\
\text { 8. Bayan } \\
\text { 9. Ma'ani } \\
\text { 10. Tafsir/Alquran } \\
\text { 11. Hadis } \\
\text { 12. Mustalah Hadis } \\
\text { 13. Tarikh } \\
\text { 14. Hadis Ahkam } \\
\text { 15. Kawaid Fiqhiyah } \\
\text { 16. Khat/Imlak } \\
\text { 17. Bahasa Inggris } \\
\text { 18. Bahasa Arab } \\
\text { 19. Ilmu Tareqat/Sulok }\end{array}$ & $\begin{array}{l}\text { 1.Dusuqi } \\
\text { 2.Mahalli \& Fathul Wahaab } \\
\text { 3.Alfiah } \\
\text { 4.Mathlub } \\
\text { 5.Sirajut Thalibin \& Ihya } \\
\text { 6.Shabban al-Malawy } \\
\text { 7. Ghayatul Ushul \& Jam'ul Jawami' } \\
\text { 8.Jauhar Maknun } \\
\text { 9.Shawi } \\
\text { 10. Majalisu Tsaniah } \\
\text { 11. Minhaatul Mughiis } \\
\text { 12. Nurul Yaqin }\end{array}$ \\
\hline
\end{tabular}

${ }^{37}$ Buto Siregar, Modernisasi, h. 148

${ }^{38}$ Ibid, h. $150-151$ 


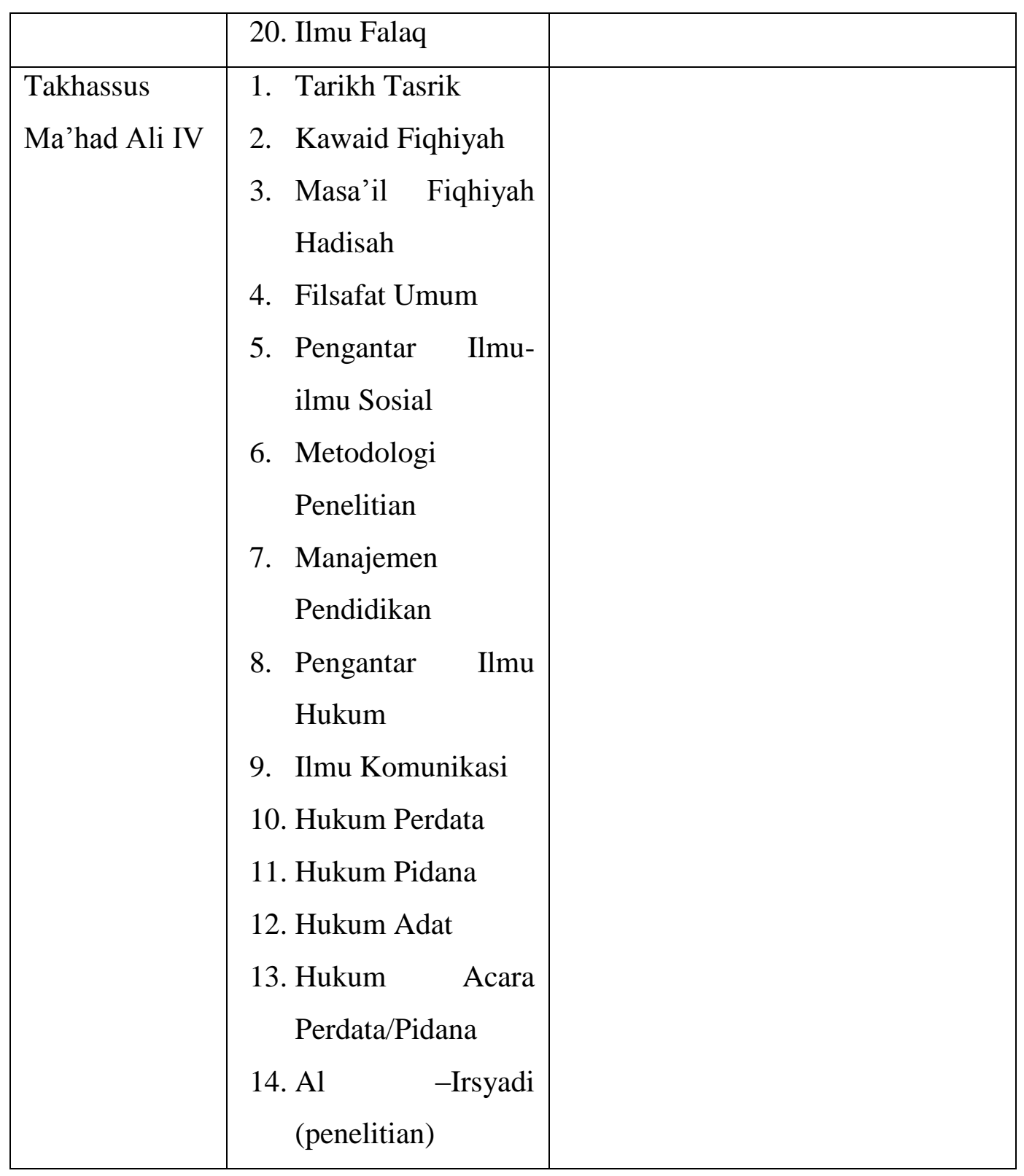

Pelestarian tradisi klasik itu juga masih terlihat dalam kurikulum Pondok Pesantren Modern Gontor Ponorogo. Sebagai lembaga pendidikan Islam modern, pesantren ini menggagas dan menerapkan kurikulum yangbiasa disebut "100\% umum dan 100\% agama”. Karenanya, di samping menambahkan pengetahuan umum, seperti ilmu alam, ilmu hayat, ilmu pasti (berhitung, aljabar dan ilmu ukur), sejarah, tata negara, ilmu bumi, ilmu pendidikan, dan ilmu jiwa, di Gontor juga tetap diajarkan ilmu-ilmu keislaman seperti akidah, tafsir, hadis, fiqih, dan ushul fiqih sebagaimana yang biasa diajarkan di pesantren tradisional. Selain itu 
ada pula mata pelajaran yang amat ditekankan dan harus menjadi karakteristik lembaga pendidikannya itu, yaitu pelajaran bahasa Arab dan bahasa Inggris. ${ }^{39}$

Belajar kitab kuning sebagai tradisi klasik pesantren tradisional juga masih dipertahankan dalam proses modernisasi di Dayah Samudera Pase Aceh Utara. Hal ini terlihat dari motivasi lahirnya dayah tersebut yang berorientasi pada lahirnya maha santri yang mampu mengeksplorasi kitab-kitab Turast (kitab kuning),di samping penguasaan kitab-kitab Mu'asarah (kontemporer).Karenanya, kurikulum yang digunakan di dayah tersebut berdasarkan sistem gabungan antara dayah salafiyah dengan penggunaan metode Talaqi untuk mendalami turats (kitab-kitab kuning) dan sistem Al-Azhar Kairo Mesir yang menggunakan metode eksplorasi dalam membahasa masalah-masalah Islam kontemporer dengan memberikan keterangan atau penjelasan dan dibarengi dengan sesi tanya jawab dan diskusi mendalam dengan penguatan apersepsi dengan kondisi atau fenomena terkini. ${ }^{40}$

Secara umum, pesantren-pesantren modern masih tetap mempertahankan penggunaan dan penguasaan terhadap buku-buku turats (kitab kuning) yang merupakan salah satu tradisi utama pesantren tradisional. Untuk memperluas pengetahuan dan wawasan santrinya mengenai buku-buku klasik, KMI Pondok pesantren modern Mawaridussalam juga biasanya mengadakan acara fathul kutub.Mungkin para santri belum mampu menentukan hukum suatu masalah kontemporer, namun mereka dituntut untuk dapat menyelesaikan permasalahan agama yang ada di masyarakat. Untuk menghadapi permasalahan-permasalahan itulah, para santri di kelas akhir KMI Mawaridussalam dilatih Bahtsul Masail atau berdiskusi dengan cara membuka kitab kuning (turats) di bawah bimbingan para musyrif. Permasalahan yang biasanya dibahas dalam kegiatan itu meliputi tafsir, fiqih, dan hadis. ${ }^{41}$

Pada sisi lain, di pesantren ini juga masih dihidupkan tradisi belajar dengan mendayagunakan masjid sebagai sarana yang merupakan salah satu tradisi kalsik yang hidup di pesantren tradisional. Pada hari-hari normal masuk kelas,

\footnotetext{
${ }^{39}$ Ismail Suardi \& Mat Busri, Kepemimpinan Transformatif Pendidikan Islam: Gontor, Kemodrenan, dan Pembelajaran Bahasa (Yogyakarta: CV. Budi Utama, 2012), h. 93

${ }^{40}$ Buto Siregar, Modernisasi,h. 204-206

${ }^{41}$ Jurnal KALAM: Kabar Mawaridussalam (Vol. 7, Mei 2017), h. 9
} 
setiap malam santri belajar bersama wali kelasnya di kelas masing-masing.Namun selama ulanga umum dan ujian semester, baik ganjil maupun genap system belajar santri diubah, yaitu belajar dipusatkan di masjid untuk santri putra, dan di masjid dan GOR untuk santri putri. ${ }^{42}$

Di samping itu, pelestarian trdisi turats (kitab kuning) di tengah geliat modernisasi itu juga muncul dalam bentuk upaya pembakuan relatif yang tidak bersifat mutlak terhadap kurikulum keagamaan di pondok pesantren. Upaya seperti ini didasari oleh alur pemikiran bahwa di satu sisi pesantren dituntut untuk beradaptasi dan berperan dalam pembaharuan, namun di sisi lain mereka juga tidak mau kehilangan jati dirinya sebagai pusat pengembangan ilmu-ilmu agama (turats). Hal ini misalnya dapat dilihat dalam pembakuan kurikulum yang dilakukan di pesantren Tegalrejo berikut:

1. Tahun pertama: Al-Jurumiyah, Safinah n-Najah, Hidayatussibyan;

2. Tahun kedua : Al-Amriti, Taqrib, Al-Amsilah at-Tasrifiyah

3. Tahun Ketiga : Alfiah, Minhaj al-Qawim;

4. Tahun keempat : Fath al-Wahhab, Jauharah al-Maknun;

5. Tahun kelima : Al-Mahalli, salah satu kitab mantiq

6. Tahun keenam: Latha'if al-Isyarah, Al-Bukhari

7. Tahun ketujuh : Ihya'

Pembakuan kurikulum materi ilmu agama seperti ini menurut Abdurrahman Wahid merupakan keberhasilan pesantren Tegalrejo dalam memenuhi standar minimalpengetahuan agama yang wajib disediakan oleh pesantren. Dengan tuntutan perubahan yang dibawa modernisasi di sana-sini, model Tegalrejo ini mnurutnya dapat dijadikan contoh pengembangan di antara model-model yang akan dijadikan upaya pembakuan kurikulum di tengah tarikan modernitas. $^{43}$

Lebih lanjut, Abdurrahman Wahid menegaskan bahwa pentingnya upaya pembakuan kurikulum demikian dikarenakan semakin lama pondok pesantren semakin dituntut untuk lebih banyak lagi berkiprah di bidang-bidang lain di luar pendidikan agama. Fungsi kemasyarakatan pondok pesantren semakin lama

\footnotetext{
${ }^{42}$ Ibid, h. 5

${ }^{43}$ Abdurrahman Wahid, Menggerakkan Tradisi: Esai-esai Pesantren (Yogyakarta: LKiS Yogyakarta, 2001), h. 165
} 
semakin menunjukkan bahwa para ulama/kiai dengan pondok pesantren mereka mengemban tugas turut memimpin proses pembangunan dalam segenap aspeknya, terutama di pedesaan. Tugas kemasyarakatan ini akan semakin banyak meminta perhatian dan menyita waktu para warga pesantren pada bidang-bidang nonagama. Menurutnya, sikap pesantren yang demikian ini berpijak pada dua ketentuan pokok yaitu :ma la yudraku kulluhu la yutroku kulluh dan al- 'akhdzu bi al-jadid ma'a al-muhafazoh bi al-qadiim al-shalih. ${ }^{44}$

Di samping itu, salah satu tradisi lain yang masih tetap dipertahankan di dunia pesantren adalah berkaitan denganpola hubungan kiai dan santri yang tetap terjaga dan bahkan menjadi kata kunci kekhasan pesantren. Hubungan yang dimaksud itu muncul dalam bentuk hubungan yang bersifat ruhaniyahspiritual/batin yang terjalin atara kiai dan santri.Jalinan hubungan yang demikian itu menyebar dalam bentuk-bentuk jaringan antar pesantren yang kokoh, baik jaringan keluarga-geneakologis, intelektual, sosial dan bahkan yang terlihat tampak di permukaan adalah jaringan kepentingan politik.Hampir semua pesantren di Indonesia, terutama di Jawa memiliki tradisi bentuk jaringan yang demikian. Pesantren-pesantren yang ada seperti yang ada di Cirebon, Kudus, Demak, Rembang, Tuban, Banyuwangi, Surabaya, Kediri, Jombang, Pasuruan, Jember, Tulungagung dan kantong-kantong daerah santri lainnya satu sama lain terjalin dalam hubungan tradisional-primordial yang demikian. ${ }^{45}$

Hubungan batin antara kiai dan santri demikian masih berlangsung terus sepanjang masa. ${ }^{46}$ Tradisi ini masih tetap bertahan di berbagai pesantren modern, sebagaimana ditemukan di pesantren Mustafawiyah Purba Baru Mandailing Natal. Di pesantren ini terjalin hubungan batin yang sangat kuat baik antara kiai dengan kiai lain, maupun antara kiai dengan para santri. Bahkan, dalam bahasa yang sedikit "mistis" bahwa sebagian kiai di sana mengawasi para santrinya lewat pengawasan batin. Pengawasan batin ini lah yang membuat jarangnya ditemukan santri yang melarikan diri dari pesantren, meskipun pada kenyataannya

\footnotetext{
${ }^{44}$ Ibid, h. 167-168

${ }^{45}$ Thonthowi, Pendidikan dan Tradisi, h. 163

${ }^{46}$ Daulay, Sejarah Pertumbuhan, h. 60
} 
lingkungan pesantren itu tidak dipagar sebagaimana pesantren lain pada umumnya. $^{47}$

Sisi lain dari tradisi klasik yang masih bertahan di lembaga-lembaga pendidikan Islam modern adalah tradisi memposisikan kiai sebagai pigur sentral. Di pesantren-pesantren tradisional, hubungan kiai dengan pengikutnya tidak sekedar hubungan antara seorang pemimpin dengan rakyatnya, tetapi juga dalam bentuk hubungan antara seorang guru dan muridnya yang selalu berkata "sami'na wa atha'na" yang berarti kami dengar dan kami taat. ${ }^{48}$ Sikap tawadhu' atau tunduk santri dan warga pesantren terhadap kiai merupakan kebiasaan yang jarang ditemukan dalam sistem pendidikan umum.Sikap hormat, ta'zim dan kepatuhan mutlak kepada kiai adalah salah satu nilai penting yang ditanamkan pertama sekali kepada santri yang biasanya diajarkan melalui kitab Ta'lim alMuta'allim. ${ }^{49}$ Bahkan, kepatuhan dan ketundukan terhadap kiai dalam segala hal, baik qaulan, fi'lan, dan taqriranmerupakan fakta ketundukan dalam kehidupan masyarakat pesantren. ${ }^{50}$

Apabila dicermati, hal ini merupakan salah satu tradisi klasik yang masih tetap berjalan dan bahkan menjadi budaya akademik di berbagai pesantren modern hingga saat ini.Misalnya, berbagai kebijakan maupun kegiatan akademik di Pesantren Modern Rasudhatul Hasanah Medan berada di bawah kendali sentral Kiai Dr. Rasyidin Bina, begitu juga misalnya di pesantren Darul 'Arafah yang berada di bawah kendali sentral Buya H.Naga Lubis.Dan ini merupakan budaya yang sudah umum di pesantren-pesantren modern lainnya.

Pada sisi lain, tradisi ini masih terus mengilhami budaya akademik di lembaga-lembaga pendidikan Islam maupun perguruan tinggi Islam dalam bentuk pembelajaran yang cenderung sangat terpusat pada guru atau dosen. Azra menyatakan bahwa secara umum di lembaga pendidikan IAIN, sistem pendidikan perkuliahan masih berlangsung dengan mengikuti apa yang disebut Freire sebagai 'the banking concept of education' (pendidikan ala bank), bukan 'problem posing

\footnotetext{
${ }^{47}$ M. Syukri Azwar Lubis, Pembinaan Kesehatan Mental Santri Melalui Konseling Islami di Pesantren Sumatera Utara (Disertasi Pascasarjana UIN SU Tahun 2017), h. 262

48 Djohan Effendi, Pembaruan Tanpa Membongkar Tradisi (Jakarta: Penerbit Buku Kompas, 2010), h. 43

${ }^{49}$ Ahmad Zahro, Tradisi IntelektualNU (Yogyakarta: LKiS Yogyakarta, 2004), h. 27
${ }^{50}$ Hajar, Kiai, h. 19.
} 
education' (pendidikan yang kritis). Berdasarkan ini, bahwa dalam proses belajar mengajar umumnya, kebanyakan dosen IAIN bertindak selaku pemilik tunggal ilmu, sedangkan mahasiswa diperlakukan sebagai wadah kosong yang harus diisi. Yang terjadi selanjutnya adalah bahwa dosesn-dosen lebih banyak berperan sebagai subjek yang aktif sedangkan mahasiswa menjadi objek yang pasif. ${ }^{51}$ Tradisi yang tidak menguntungkan ini, mau tidak mau tentu harus diakui belum sepenuhnya bisa dihilangkan dari lembaga-lembaga pendidikan kita saat ini, termasuk di IAIN, bahkan pasca konversi menjadi UIN.

Berikutnya, sebagai konsekuensi model tradisi di atas, maka tradisi bahwa santri harus taat kepada kiai masih terus berlanjut di lembaga-lembaga pendidikan Islam, khususnya di perguruan tinggi.Kasus IAIN menurut Azra hingga saat ini belum mampu mengubah sikap dasar kebanyakan mahasiswanya yang kurang memiliki daya kreativitas dan kritisisme di mana pola pikir yang demikian mereka warisi dari pesantren. ${ }^{52}$

Di samping itu, sebagaimana telah dikemukakan sebelumnya bahwa salah satu tradisi lain dari pendidikan Islam klasik itu adalah kecenderungan hanya memfokuskan diri pada ilmu-ilmu agama semata. ${ }^{53}$ Tradisi yang demikian, mau tidak mau harus diakuibelum mampu disingkirkan sepenuhnya dari budaya akademik di lembaga pendidikan Islam modern, misalnya dalam bentuk kompartementalisasi.Kompartementalisasi di lingkungan IAIN menurut Azra adalah dalam bentuk fakultas dan penjurusan sejak mahasiswa melangkaahkan kaki di perguruan tinggi.Akibat tradisi ini, mahasiswa cenderung mempunyai pemahaman yang terpilah-pilah tentang Islam.mereka yang memasuki Fakultas Ushuluddin, misalnya kurang apresiatif terhadap syari'ah; mereka yang memasuki Fakultas Tarbiyah sangat lemah dalam bidang pemikiran kalam atau filsafat Islam.Karenanya, menurutnya untuk penguasaan yang integral dan komprehenshif

${ }^{51}$ Azyumardi Azra, Pendidikan Islam: Tradisi dan Modernisasi Menuju Milenium Baru (Jakarta: Logos Wacana Ilmu, 1999), h. 163-164

${ }^{52}$ Ibid, h. 164

${ }^{53}$ Meskipun pada kenyataannya, pesantren-pesantren tradisional tidaklah sama sekali kosong dari pelajaran umum, namun terdapat kecenderungan bahwa kurikulumnya lebih dominan pada ilmu-ilmu agama. 
terhadap Islam, seyogyanya tidak ada pembagian kefakultasan dan jurusan setidak-tidaknya dalam 2 tahun pertama program $S 1 .{ }^{54}$

Keadaan yang sama dapat juga dilihat di pesantren-pesantren modern. Meskipun sudah ada upaya untuk meminimalisir tradisi dikotomis tersebut, namun pesantren belum mampu mengintegrasikan antardisiplin keilmuan secara utuh.Misalnya antara ilmu umum dan agama, meskipun sama-sama diajarkan, namun dalam praktiknya tetap saja dibiarkan berjalan sendiri-sendiri sehingga tidak menghasilkan pemahaman yang benar-benar baru dan mencerahkan umat. ${ }^{55}$

Pada sisi lain, sebagaimana dikemukakan Azra bahwa sisa-sisa tradisi kalsik pasca modern dapat dilihat dari kecenderungan lingkup kajian disertasi di lingkungan IAIN. Menurutnya, sampai Desember tahun 1996, disertasi yang ditulis oleh mahasiswa pascasarjana IAIN Jakarta hampir $70 \%$ membahas topiktopik yang berkaitan dengan ilmu-ilmu agama, seperti fiqih, kalam, tafsir, tasawuf, dan hadis, dan sisanya berkaitan dengan topik yang berada "di pinggiran" ilmu-ilmu agama, seperti sejarah, politik, dan sosial. Berdasarkan ini, maka secara umum dapat dikatakan bahwa kecenderungan kajian Islam pada PPS IAIN Jakarta masa itu masih bertumpu pada ilmu-ilmu tradisional Islam. ${ }^{56}$

Sehubungan dengan itu, meskipun belakangan ini telah terjadi perkembangan wilayah kajian disertasi maupun tesis di lingkungan IAIN atau UIN, namun kecenderungan kajian pada topik-topik yang berhubungan dengan ilmu agama tampak masih tetap mendominasi saat ini.

Dalam konteks madrasah, tradisi dikotomis itu juga masih terjadi. Meskipun pasca SKB Tiga Menteri, ilmu agama telah dimasukkan 30\% ke dalam kurikulumnya, namun pada praktiknya ilmu agama tersebut cenderung diperlakukan hanya sekedar sebagai pelengkap untuk mempertahankan ciri khas sekolah Islam. ini kemudian membuat citra madrasah rendah di mata umat. ${ }^{57}$

Di sisi lain, untuk mengatasi problem yang terjadi di madrasah itu, maka dimunculkan lah Madrasah Aliyah Program Khusus (MAPK).Hal ini juga dapat dipandang sebagai upaya mempertahankan tradisi klasik pesantren yang sengaja

\footnotetext{
${ }^{54}$ Azra, Pendidikan Islam, h. 168

${ }^{55}$ Abd A'la, Pembaruan Pesantren (Yogyakarta: Pustaka Pesantren, 2006), h. 21

${ }^{56}$ Azra, Pendidikan Islam, h. 182-183

${ }^{57}$ Huda, Sejarah Sosial, h. 323
} 
dibuka untuk menghadapi kenyataan bahwa lulusan madrasah, khususnya yang berstatus negeri pada umumnya tanggung dalam pengetahuan umum, dan juga dangkal dalam penguasaan agama.Karenanya, dalam konsepnya, MAPK dimaksudkan sebagai lembaga pendidikan formal non-pesantren yang berperan sebagai penyambung (setidaknya sebahagian dari) 'tradisi pesantren' yang tujuannya adalah untuk ber-tafaqquh fiddin, dengan trade mark dan unsur utamanya adalah mengkaji kitab kuning.Secara substantif, hubungan MAPK dan tafaqquh fiddin bagaikan wadah dan isi, MAPK merupakan wadah sedangkan isinya adalah tafaqquh fiddin.Di sisi lain MAPK merupakan bagian dari madrasah (MA) yang ada pada saat ini dengan struktur program kurikulum yang porsi pelajaran agamanya $70 \%{ }^{58}$

\section{Kesimpulan}

Pembahasan di atas membawa pada kesimpulan bahwa pendidikan Islam dalam menghadapi arus modernisasi masih tetap mempertahankan berbagai tradisi-tradisi tertentu yang sebagiannya berimplikasi positif, namun sebagian lagi berimplikasi negatifbagi upaya memajukan pendidikan Islam di era modern.Tradisi-tradisi itu berkaitan dengan kurikulum, metode pembelajaran, budaya akademik dan lainnya.

\footnotetext{
${ }^{58}$ Ibid, h. 324
} 


\section{Pustaka Acuan}

Abdurrahman Wahid, Menggerakkan Tradisi: Esai-esai Pesantren (Yogyakarta: LKiS Yogyakarta, 2001)

Ahmad Zahro, Tradisi IntelektualNU (Yogyakarta: LKiS Yogyakarta, 2004)

Azyumardi Azra, Islam Reformis, Dinamika Intelektual dan Gerakan (Jakarta: Raja Grafindo Persada, 1999)

Azyumardi Azra, Pendidikan Islam: Tradisi dan Modernisasi Menuju Milenium Baru (Jakarta: Logos Wacana Ilmu, 1999)

Binti Maunah, Tradisi Intelektual Santri Dalam Tantangan dan Hambatan Pendidikan Pesantren di Masa Depan (Yogyakarta: Teras, 2009)

Djohan Effendi, Pembaruan Tanpa Membongkar Tradisi (Jakarta: Penerbit Buku Kompas, 2010)

Fazlur Rahman, Islam dan Modernitas: Tentang Transformasi Intelektual (Bandung: Pustaka, 1985)

Fazlur Rahman, Islam: Sejarah Pemikiran dan Peradaban (Bandung: Mizan, 2017)

Haidar Putra Daulay, Pendidikan Islam dalam Sistem Pendidikan Nasional di Indonesia (Jakarta: Prenada Media Group, 2012)

Haidar Putra Daulay, Sejarah Pertumbuhan dan Pembaruan Pendidikan Islam di Indonesia (Jakarta: Prenada Media Group, 2012)

Hasan Asari, Modernisasi Islam: Tokoh, Gagasan, dan Gerakan (Bandung: Citapustaka Media, 2002)

Hasbullah, Sejarah Pendidikan islam di Indonesia(Jakarta: RajaGrafindo Persada, 1995)

Ibnu Hajar, Kiai Di Tengah Pusaran Politik Antara Petaka dan Kuasa, (Yogyakarta: IRCisoD, 2009)

Imron Arifin, Kepemimpinan Kiai, Kasus: Pondok Pesantren Tebuireng (Malang: Kalimasahada Press, 1993)

Ismail Suardi \& Mat Busri, Kepemimpinan Transformatif Pendidikan Islam: Gontor, Kemodrenan, dan Pembelajaran Bahasa (Yogyakarta: CV. Budi Utama, 2012)

Jurnal KALAM: Kabar Mawaridussalam (Vol. 7, Mei 2017) 
Karel A. Steenbrink, Pesantren, Madrasah, Sekolah: Pendidikan Islam dalam Kurun Modern(Jakarta: LP3ES, 1991)

Mark R.Woodward, Modernity And The Disenchantment Of Life: A MuslimChristian Contrast Dalam Johan Meuleman (Ed.), Muslim Attitudes Towards Modernity and Identity (New York: RoutledgeCurzon, 2002)

Martin Van Bruinessen, Traditionalist Muslims in A Modernizing World: The Nahdlatul Ulama and Indonesia's New Order Politics, Factional Conflict, and The Search for A New Discourse, Diterjemahkan Farid Wajidi, (Yogyakarta: LKiS Yogyakarta, 1999)

Muhammad Abed Al Jabiri, Post Tradisionalisme Islam, Terjemahan (Yogyakarta: LKiS, 2000)

Mujamil Qomar, Pesantren Dari Transformasi Metodologi Menuju Demokratisasi Institusi (Jakarta: Erlangga, 2002)

M. Syukri Azwar Lubis, Pembinaan Kesehatan Mental Santri Melalui Konseling Islami di Pesantren Sumatera Utara (Disertasi Pascasarjana UIN SU Tahun 2017)

Nor Huda, Sejarah Sosial Intelektual Islam di Indonesia (Jakarta: RajaGrafindo Persada, 2015)

Seyyed Hossein Nasr, Islam Tradisi di Tengah Kancah Dunia Modern (Bandung: Penerbit Pustaka, 1994)

Thonthowi, "Pendidikan dan Tradisi: Menakar Tradisi Pendidikan Pesantren" dalam Tadris: Jurnal Pendidikan Islam Fak. Tarbiyah STAIN Pamekasan (Vol. 3 No. 2. 2008)

William Montogomery Watt, Islamic Fundamentalism and Modernity, Terjemahan Kurnia Sastrapraja dan Badri Khaeruman (Bandung: Pustaka Setia, 2003)

Zamakhsyari Dhofier, Tradisi Pesantren Studi tentang Pandangan Hidup Kiai (Jakarta: LP3ES, 1982)

Zulfikar Ali Buto Siregar, Modernisasi Dayah di Aceh (Disertasi, UIN Sumatera Utara, 2015) 